\title{
MENENTUKAN PRIORITAS PERBAIKAN PENGEMBANGAN PRODUK ALAT PEMBUKA TUTUP GALON DENGAN QUALITY FUNCTION DEPLOYMENT
}

\section{[Determining the Priority for Product Development Improvement Gallon Cap Opener Tool with Quality Function Deployment]}

\author{
Glisina Dwinoor Rembulan ${ }^{1)}$, Tony Wijaya ${ }^{1)}$, Andrew Ruslie ${ }^{1)}$, Jordy ${ }^{1)}$, Rama Adi Saputra \\ Sunadynatha ${ }^{1)}$ \\ ${ }^{1)}$ Program Studi Teknik Industri, Universitas Bunda Mulia \\ Diterima: 7-10-2020 / Disetujui: 31-05-2021
}

\begin{abstract}
The bottled water sales industry continues to grow in line with the high demand for clean water by the community. The market share of the bottled water industry to the beverage industry reaches $84 \%$ and accounts for $3.3 \%$ of gross domestic product (GDP). Gallon packaging is one of the packages that is widely used by the community today. Several problems were encountered when opening the gallon cap. These problems can be overcome by developing a product for a gallon cap opener that is tailored to customer needs or Voice of Customer (VOC). VOC was collected and translated through two questionnaires, namely an open questionnaire and a closed questionnaire. The first questionnaire is the process of collecting data through open interviews with gallon water customers. Meanwhile, the second questionnaire was distributed to the same customers for further assessment. The method used in this research is Quality Function Deployment (QFD) by creating a House of Quality (HOQ) matrix. The results showed that there were 12 VOCs, 10 technical responses, and a priority order of improvement in succession, namely (1) the use of material on the tool (plastic or stainless steel), (2) the weight of the tool, (3) the diameter of the handle, (4) the diameter of the tool. gallon cap opener, (5) the number of additional features on the tool, (6) the number of movements in the use of the tool, (7) the length of the handle, (8) the power used, (9) color selection (red, yellow, green), and (10) production costs.
\end{abstract}

Keywords: Voice of Customer, Quality Function Deployment, House of Quality

\begin{abstract}
ABSTRAK
Industri penjualan air minum dalam kemasan terus berkembang seiring tingginya kebutuhan air bersih oleh masyarakat. Pangsa pasar industri air minum dalam kemasan terhadap industri minuman mencapai $84 \%$ dan menyumbang 3,3\% terhadap produk domestik bruto (PDB). Kemasan galon adalah salah satu kemasan yang banyak digunakan oleh masyarakat saat ini. Telah ditemukan beberapa masalah ketika membuka tutup galon. Masalah-masalah tersebut dapat diatasi dengan melakukan pengembangan produk alat pembuka tutup galon yang disesuaikan dengan kebutuhan pelanggan atau Voice of Customer (VOC). VOC dikumpulkan dan diterjemahkan melalui dua kuesioner, yaitu kuesioner terbuka dan kuesioner tertutup. Kuesioner pertama adalah proses pengumpulan data melalui wawancara terbuka kepada pelanggan air galon. Sementara kuesioner kedua disebarkan kepada pelanggan yang sama untuk dilakukan penilaian lebih lanjut. Metode yang digunakan pada penelitian ini adalah Quality Function Deployment (QFD) dengan membuat matriks House of Quality (HOQ). Hasil penelitian menunjukkan terdapat 12 VOC, 10 respon teknis, dan urutan prioritas perbaikan secara berturut-turut yaitu (1) penggunaan material pada alat (plastik atau stainless steel), (2) berat alat, (3) diameter pegangan, (4) diameter alat pembuka tutup galon, (5) jumlah fitur tambahan pada alat, (6) jumlah gerakan dalam penggunaan alat, (7) panjang pegangan, (8) tenaga yang digunakan, (9) pemilihan warna (merah, kuning, hijau), dan (10) biaya produksi.
\end{abstract}

Kata Kunci: Voice of Customer, Quality Function Deployment, House of Quality

\footnotetext{
*Korespondensi Penulis:

E-mail: grembulan@bundamulia.ac.id
} 


\section{PENDAHULUAN}

Industri penjualan air minum dalam kemasan terus berkembang seiring tingginya kebutuhan air bersih oleh masyarakat. Air adalah kebutuhan pokok manusia yang menunjang aktivitas sehari-hari. Pangsa pasar industri air minum dalam kemasan terhadap industri minuman mencapai $84 \%$ dan menyumbang 3,3\% terhadap produk domestik bruto (PDB) (Kementerian Perindustrian, 2019). Jumlah industri penjualan air minum dalam kemasan di Indonesia pada tahun 2019 mencapai 700 perusahaan (Rini, 2019).

Produksi air minum dalam kemasan di Indonesia terus mengalami kenaikan. Persentase konsumsi air minum dalam kemasan pada tahun 2018 mencapai $36,28 \%$ dan mengalami peningkatan pada tahun 2019 mencapai 38,25\% (Badan Pusat Statistik, 2019). Salah satu kemasan yang banyak digunakan oleh masyarakat adalah kemasan galon 19 liter. Kemasan galon dapat dilakukan isi ulang dan lebih ramah lingkungan sehingga menjadi pilihan oleh masyarakat (Ramadhan, 2020).

Beberapa masalah sering terjadi pada masyarakat saat membuka tutup galon. Hasil wawancara awal kepada masyarakat ditemukan beberapa masalah antara lain sulit membuka segel tutup galon jika menggunakan pisau, tutup galon sering tidak terbuka semuanya jika menggunakan pisau, risiko cedera yang tinggi pada tangan jika membuka tutup galon menggunakan pisau, dan tangan terasa sakit jika membuka tutup galon secara manual tanpa alat bantu. Masalah-masalah tersebut dapat ditangani dengan melakukan pengembangan produk alat pembuka tutup galon berdasarkan kebutuhan masyarakat sehingga dapat memberikan kemudahan saat membuka tutup galon. Produk yang didesain seyogyanya seusai dengan kebutuhan konsumen dengan tetap memerhatikan faktor keamanan penggunaan dan daya tarik produk. Penelitian sebelumnya mengevaluasi tentang keselamatan, kesehatan, keamanan, kenyamanan, dan daya tarik (Christian \& Rembulan, 2019; Rembulan et al., 2015). Lebih jauh lagi, inovasi produk seharusnya dapat memberikan manfaat kepada konsumen yang potensial serta berpengaruh pada harga jual (Filscha Nurprihatin, Andry, et al., 2021; Rembulan, 2017).

Kebutuhan pelanggan atau yang lebih dikenal dengan Voice of Customer (VOC) adalah sesuatu yang sangat penting bagi perusahaan untuk membantu meningkatkan produk dan layanan mereka (Aguwa et al., 2017; Sachamanorom \& Senoo, 2016). Perspektif konsumen dapat menjadi langkah awal yang tepat dalam proses menuju industrialisasi (Rembulan, 2019). VOC yang telah didapatkan akan digunakan untuk pengembangan produk alat pembuka tutup galon dengan menggunakan metode Quality Function Deployment (QFD). Metode QFD efektif untuk mengevaluasi harapan pelanggan dengan mengubah kebutuhan subjektif menjadi kriteria kualitas yang objektif dan menyarankan prioritas respon teknis bagi produsen dalam merancang dan mengembangkan produk (Ho et al., 2018).

Alat bantu yang digunakan untuk memudahkan pengambilan keputusan dalam proses QFD adalah House of Quality (HOQ) (Cahya, 2018). HOQ adalah alat yang paling dikenal untuk representasi metode QFD (Kasan \& Yohanes, 2017). Urutan prioritas perbaikan pengembangan produk dapat diketahui dari HOQ. Beberapa penelitian yang menggunakan QFD telah dilakukan di layanan pemerintah (Alsaadi et al., 2018), infrastruktur kesehatan (Dehe \& Bamford, 2017), otomotif (Padagannavar, 2016), pendidikan (Singh \& Rawani, 2019), dan makanan (Ekawati \& Bazarado, 2016).

Konsumen juga harus mengerti dengan fungsi dan cara pakai produk. Hal ini penting untuk mengantisipasi dan mengatasi kondisi bahaya yang muncul (Rembulan, 2020). VOC dapat berisi tentang tuntutan konsumen terhadap kualitas produk (Rembulan, 2018). Penelitian sebelumnya mereduksi VOC menggunakan Analisis Faktor (Rembulan, Wijaya, Ruslie, et al., 2020). Penelitian ini bertujuan untuk mengidentifikasi jumlah VOC, menentukan jumlah technical response, dan mengetahui urutan prioritas perbaikan pada pengembangan produk alat pembuka tutup galon dengan menggunakan metode QFD. 


\section{TINJAUAN PUSTAKA}

\subsection{Quality Function Deployment (QFD)}

Quality Function Deployment (QFD) pertama kali diperkenalkan oleh Yoji Akao di perusahaan Mitsubishi pada tahun 1972 (Sulistiyoningrum et al., 2017). QFD adalah alat yang digunakan untuk merancang produk untuk memenuhi kebutuhan pelanggan (Priyono, 2016). Fokus utama QFD yaitu terhadap spesifikasi suatu produk atau jasa yang diharapkan oleh pelanggan yang dikenal dengan VOC (Lusiani et al., 2017). Tujuan utama QFD yaitu memastikan tingkat kualitas produk pada setiap tahapan siklus sehingga dapat menjamin hasil akhir yang sesuai dengan kebutuhan dan harapan pelanggan (Klochkov et al., 2016).

Beberapa manfaat QFD bagi perusahaan antara lain (Ritonga et al., 2018):

1. Mengumpulkan masukan dan umpan balik dari setiap pelanggan terhadap perusahaan.

2. Memfokuskan kepada persyaratan yang spesifik sehingga dapat mengurangi waktu pengembangan produk.

3. Memfokuskan terhadap kerjasama tim karena setiap keputusan diambil berdasarkan hasil diskusi dan brainstorming.

4. Menghasilkan dokumen yang komprehensif mengenai semua data yang berkaitan dengan persyaratan pelanggan.

5. Memusatkan perancangan produk dan jasa sesuai dengan kebutuhan pelanggan.
6. Mengutamakan kegiatan-kegiatan desain yang berpusat pada kebutuhan pelanggan.

7. Menganalisis kinerja dari produk perusahaan dalam memenuhi kebutuhan pelanggan.

8. Mengurangi waktu dalam pemasaran produk-produk.

9. Mengurangi banyaknya perubahan desain.

10.Mendorong terciptanya kerja tim dan menghancurkan rintangan antar bagian.

11.Menyediakan cara dalam pembuatan dokumen dan dasar yang kokoh untuk digunakan dalam pengambilan keputusan rancangan.

\subsection{House of Quality (HOQ)}

House of Quality (HOQ) merupakan sebuah matriks yang mendokumentasikan dan menetapkan semua proses dalam penerapan QFD (Bolar et al., 2017). HOQ adalah alat perencanaan utama dalam QFD (Sukania et al., 2017). HOQ digunakan untuk menerjemahkan persyaratan pelanggan, hasil riset pasar, dan benchmarking data ke dalam target teknis prioritas (Kasan \& Yohanes, 2017). Fokus utama saat membangun HOQ yaitu kebutuhan konsumen sehingga proses desain dan pengembangan dapat sesuai dengan keinginan pelanggan (Piri et al., 2017). Gambar 1 menunjukkan bagian-bagian pada HOQ (Cahya, 2018). Berdasarkan Gambar 1 dapat dilihat bahwa terdapat 6 bagian utama pada HOQ.

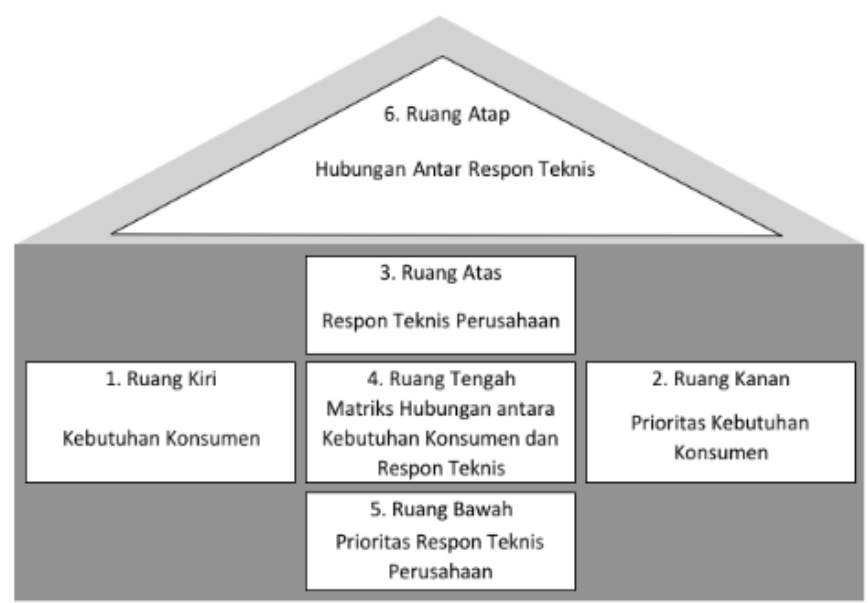

Gambar 1. Bagian-Bagian House of Quality (HOQ) Sumber : Cahya (2018) 
berikut:

Bagian-bagian dari HOQ yaitu sebagai

1. Voice of Customer (VOC) adalah daftar kebutuhan dan keinginan pelanggan yang digunakan dalam proses pengembangan produk (Yustian, 2015). VOC dapat diperoleh melalui beberapa cara antara lain survei, wawancara, grup diskusi, dan metode serupa lainnya (Erdil \& Arani, 2018).

2. Planning matrix yaitu persepsi pelanggan yang dilihat dari survei pasar dan terdiri dari kepentingan relatif dari persyaratan konsumen, perusahaan, kinerja perusahaan dan pesaing untuk memenuhi persyaratan tersebut (Kasan \& Yohanes, 2017).

3. Technical response adalah langkah lanjutan untuk menerjemahkan kebutuhan pelanggan yang bersifat nonteknis menjadi teknis sehingga perencanaan dan pengembangan dapat dilakukan dengan baik (Yushila et al., 2017). Technical response berkaitan dengan spesifikasi produk yang ditetapkan perusahaan (Tannady, 2015).

4. Relationship matrix yaitu keterkaitan hubungan antara VOC dengan Technical response (Kasan \& Yohanes, 2017).

5. Technical priorities adalah perhitungan nilai kepentingan absolut dan relatif. Nilai kepentingan absolut didapatkan dari hubungan antara VOC dengan technical response sedangkan nilai kepentingan relatif didapatkan dari nilai kepentingan absolut yang dinyatakan dalam persen kumulatif. Dua parameter ini digunakan untuk menentukan technical response yang harus diprioritaskan (Tannady, 2015).

6. Technical correlation yaitu korelasi antara setiap technical response yang dibandingkan satu sama lain apakah saling mendukung atau saling bertentangan (Muttalib et al., 2020).

\section{METODOLOGI}

Pengumpulan data pada penelitian ini dilakukan dengan cara wawancara dan penyebaran kuesioner. Jenis data yang digunakan adalah data primer karena didapatkan secara langsung oleh peneliti dari sumber utama. Diagram alir penelitian menunjukkan urutan-urutan proses dari penelitian ini. Gambar 2 menunjukkan diagram alir penelitian.

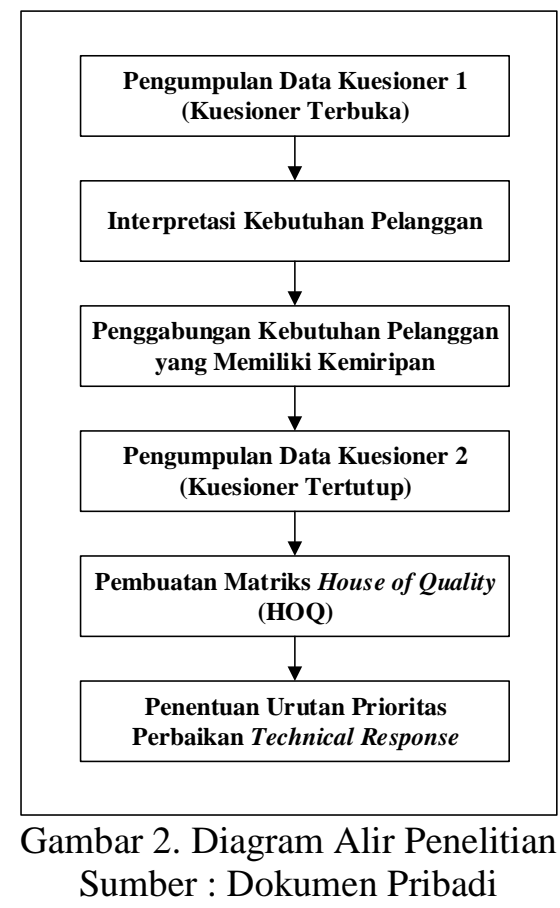

Gambar 2 menunjukkan 6 langkah yang harus dilakukan dalam penelitian antara lain:

1. Mengumpulkan data melalui kuesioner 1 (kuesioner terbuka). Data dikumpulkan melalui proses wawancara kepada pelanggan air galon dengan memberikan 6 pernyataan.

2. Menginterpretasikan kebutuhan pelanggan. Interpretasi kebutuhan pelanggan dilakukan menggunakan jawaban pelanggan air galon pada kuesioner 1.

3. Menggabungkan kebutuhan pelanggan yang sama. Kebutuhan pelanggan akan digabungkan menjadi satu kebutuhan saja apabila terdapat kemiripan pada kebutuhan pelanggan.

4. Mengumpulkan data melalui kuesioner 2 (kuesioner tertutup). Data dikumpulkan dengan cara menyebarkan kuesioner dengan menggunakan skala penilaian likert dengan skor 1 hingga 5 .

5. Membuat matriks HOQ.

6. Menentukan urutan prioritas perbaikan technical response yang akan dilakukan pada pengembangan produk alat pembuka tutup galon. 


\section{HASIL DAN PEMBAHASAN}

\subsection{Kuesioner 1 (Kuesioner Terbuka)}

Tahap ini adalah proses pengumpulan data melalui wawancara terbuka kepada pelanggan air galon. Tujuan wawancara dilakukan adalah untuk mengetahui masalah yang dihadapi dan kebutuhan yang diinginkan oleh pelanggan. Proses wawancara menggunakan 6 pertanyaan yang telah disusun oleh peneliti. Tabel 1 menunjukkan 6 pertanyaan yang digunakan pada kuesioner 1 (kuesioner terbuka). Berdasarkan Tabel 1 dapat dilihat bahwa hal utama yang ingin diketahui adalah alat yang digunakan, hal yang disukai dari produk saat ini, hal yang tidak disukai dari produk saat ini, dan perbaikan apa yang diinginkan untuk pengembangan produk alat pembuka tutup galon.

Tabel 1. Pertanyaan Kuesioner 1 (Kuesioner Terbuka)

\begin{tabular}{cl}
\hline No & \multicolumn{1}{c}{ Pertanyaan } \\
\hline $\mathbf{1}$ & $\begin{array}{l}\text { Alat apa yang sering anda gunakan untuk } \\
\text { membuka galon? }\end{array}$ \\
$\mathbf{2}$ & $\begin{array}{l}\text { Apa yang anda suka dengan alat pembuka } \\
\text { tutup galon saat ini? }\end{array}$ \\
$\mathbf{3}$ & $\begin{array}{l}\text { Apa yang anda tidak suka dengan alat } \\
\text { pembuka tutup galon saat ini? }\end{array}$ \\
$\mathbf{4}$ & $\begin{array}{l}\text { Apakah anda setuju jika dilakukan } \\
\text { pengembangan produk alat pembuka tutup } \\
\text { galon? }\end{array}$ \\
$\mathbf{5}$ & $\begin{array}{l}\text { Perbaikan apa yang anda inginkan dari alat } \\
\text { pembuka tutup galon? (Warna, bentuk, } \\
\text { material dan ukuran) }\end{array}$ \\
$\mathbf{6} \quad \begin{array}{l}\text { Berapa kisaran harga alat pembuka tutup } \\
\text { galon yang diinginkan setelah dilakukan } \\
\text { pengembangan produk? }\end{array}$ \\
\hline
\end{tabular}

\subsection{Interpretasi Pernyataan Kebutuhan Pelanggan}

Kebutuhan pelanggan didapatkan dari hasil interpretasi jawaban pelanggan pada kuesioner 1 (kuesioner terbuka). Setiap kebutuhan pelanggan yang memiliki kemiripan akan digabungkan menjadi satu kebutuhan saja. Tabel 2 menunjukkan daftar kebutuhan pelanggan yang telah dilakukan interpretasi. Berdasarkan Tabel 2 dapat terlihat bahwa didapatkan 12 kebutuhan pelanggan setelah proses penggabungan. 12 kebutuhan pelanggan ini akan digunakan menjadi VOC.
Tabel 2. Daftar Kebutuhan Pelanggan

\begin{tabular}{cl}
\hline No & \multicolumn{1}{c}{ Kebutuhan Pelanggan } \\
\hline $\mathbf{1}$ & $\begin{array}{l}\text { Alat pembuka tutup galon yang dapat } \\
\text { digunakan dengan mudah }\end{array}$ \\
$\mathbf{2}$ & $\begin{array}{l}\text { Alat pembuka tutup galon yang dapat } \\
\text { membuka segel galon dengan mudah }\end{array}$ \\
$\mathbf{3}$ & $\begin{array}{l}\text { Alat pembuka tutup galon yang dapat } \\
\text { mengangkat tutup galon dengan mudah setelah }\end{array}$ \\
& segel nya dibuka \\
$\mathbf{4}$ & $\begin{array}{l}\text { Alat pembuka tutup galon yang dapat } \\
\text { digunakan dengan aman oleh semua orang }\end{array}$ \\
$\mathbf{5}$ & $\begin{array}{l}\text { Alat pembuka tutup galon yang dapat } \\
\text { mengurangi resiko cidera saat membuka tutup }\end{array}$ \\
& $\begin{array}{l}\text { galon } \\
\mathbf{6}\end{array}$ \\
& $\begin{array}{l}\text { Alat pembuka tutup galon memiliki pegangan } \\
\text { yang tidak licin }\end{array}$ \\
$\mathbf{7}$ & $\begin{array}{l}\text { Alat pembuka tutup galon memiliki fitur } \\
\text { tambahan }\end{array}$ \\
$\mathbf{8}$ & $\begin{array}{l}\text { Alat pembuka tutup galon terbuat dari material } \\
\text { yang aman, ringan, dan tahan lama }\end{array}$ \\
$\mathbf{9}$ & $\begin{array}{l}\text { Alat pembuka tutup galon memiliki bentuk } \\
\text { yang sesuai dengan tutup galon }\end{array}$ \\
$\mathbf{1 0}$ & $\begin{array}{l}\text { Alat pembuka tutup galon memiliki bentuk } \\
\text { dengan diameter yang adjustable }\end{array}$ \\
$\mathbf{1 1}$ & $\begin{array}{l}\text { Alat pembuka tutup galon memiliki warna } \\
\text { yang cerah }\end{array}$ \\
$\mathbf{1 2}$ & $\begin{array}{l}\text { Alat pembuka tutup galon memiliki harga } \\
\text { yang terjangkau }\end{array}$ \\
\hline &
\end{tabular}

\subsection{Kuesioner 2 (Kuesioner Tertutup)}

Kuesioner 2 adalah kuesioner yang disebarkan kepada pelanggan yang sama pada kuesioner 1 untuk dilakukan penilaian. Skala penilaian yang digunakan yaitu skala likert dengan rentang skor 1 hingga 5 (sangat tidak penting, tidak penting, netral, penting, sangat penting). Pernyataan pada kuesioner ini menggunakan kebutuhan pelanggan yang telah dilakukan proses penggabungan. Tabel 3 menunjukkan pernyataan kuesioner 2 (kuesioner tertutup). Berdasarkan Tabel 3 dapat dilihat bahwa terdapat 12 pernyataan yang harus dinilai oleh pelanggan sesuai tingkat kepentingan mereka masing-masing.

\subsection{Matriks House of Quality (HOQ)}

Pembuatan matriks House of Quality (HOQ) melalui beberapa tahap yaitu menentukan VOC, menentukan technical response, membuat relationship matrix, membuat technical correlation, menghitung nilai kepentingan absolut dan relatif, dan menentukan urutan prioritas perbaikan yang dapat dilakukan. 


\section{Voice of Customer (VOC)}

VOC didapatkan dari daftar kebutuhan pelanggan pada kuesioner 1. Pada VOC juga terdapat nilai kepentingan pelanggan setiap kebutuhan pelanggan. Nilai ini diperoleh melalui penilaian pelanggan pada kuesioner 2. Perhitungan nilai kepentingan pelanggan ditunjukkan pada persamaan 1 (Sofyan \& Amri, 2018).

$$
\bar{X}=\frac{\sum_{i=1}^{n} D K_{i}}{n}
$$

dimana:

$D K_{i} \quad$ : derajat kepentingan responden ke- $i$

$n \quad$ : jumlah responden

Tabel 4 menunjukkan VOC dan nilai kepentingan pelanggan. Berdasarkan Tabel 4 dapat dilihat bahwa terdapat 12 VOC yang akan digunakan untuk pembuatan matriks HOQ dan terdapat 10 VOC yang memiliki nilai kepentingan $\geq 4$ dan 2 VOC memiliki nilai kepentingan $<4$.

Tabel 3. Pernyataan Kuesioner 2 (Kuesioner Tertutup)

\begin{tabular}{|c|c|c|c|c|c|c|}
\hline No. & Pernyataan & STP & TP & $\mathrm{N}$ & $\mathrm{P}$ & SP \\
\hline 1 & $\begin{array}{l}\text { Alat pembuka tutup galon yang dapat digunakan dengan mudah oleh } \\
\text { semua orang }\end{array}$ & & & & & \\
\hline 2 & $\begin{array}{l}\text { Alat pembuka tutup galon yang dapat membuka segel galon dengan } \\
\text { mudah }\end{array}$ & & & & & \\
\hline 3 & $\begin{array}{l}\text { Alat pembuka tutup galon yang dapat mengangkat tutup galon dengan } \\
\text { mudah setelah segelnya dibuka }\end{array}$ & & & & & \\
\hline 4 & $\begin{array}{l}\text { Alat pembuka tutup galon yang dapat digunakan dengan aman oleh } \\
\text { semua orang }\end{array}$ & & & & & \\
\hline 5 & $\begin{array}{l}\text { Alat pembuka tutup galon yang dapat mengurangi resiko cidera saat } \\
\text { membuka tutup galon }\end{array}$ & & & & & \\
\hline 6 & Alat pembuka tutup galon memiliki pegangan yang tidak licin & & & & & \\
\hline 7 & Alat pembuka tutup galon memiliki fitur tambahan & & & & & \\
\hline 8 & $\begin{array}{l}\text { Alat pembuka tutup galon terbuat dari material yang aman, ringan, dan } \\
\text { tahan lama }\end{array}$ & & & & & \\
\hline 9 & $\begin{array}{l}\text { Alat pembuka tutup galon memiliki bentuk yang sesuai dengan tutup } \\
\text { galon }\end{array}$ & & & & & \\
\hline 10 & $\begin{array}{l}\text { Alat pembuka tutup galon memiliki bentuk dengan diameter yang } \\
\text { adjustable }\end{array}$ & & & & & \\
\hline 11 & Alat pembuka tutup galon memiliki warna yang cerah & & & & & \\
\hline 12 & Alat pembuka tutup galon memiliki harga yang terjangkau & & & & & \\
\hline
\end{tabular}

Tabel 4. Voice of Customer (VOC) dan Nilai Kepentingan Pelanggan

\begin{tabular}{|c|c|c|}
\hline No & Voice of Customer (VOC) & $\begin{array}{l}\text { Nilai Kepentingan } \\
\text { Pelanggan }\end{array}$ \\
\hline 1 & $\begin{array}{l}\text { Alat pembuka tutup galon yang dapat digunakan dengan mudah oleh semua } \\
\text { orang }\end{array}$ & 4,1429 \\
\hline 2 & Alat pembuka tutup galon yang dapat membuka segel galon dengan mudah & 4,4286 \\
\hline 3 & $\begin{array}{l}\text { Alat pembuka tutup galon yang dapat mengangkat tutup galon dengan mudah } \\
\text { setelah segelnya dibuka }\end{array}$ & 4,1429 \\
\hline 4 & $\begin{array}{l}\text { Alat pembuka tutup galon yang dapat digunakan dengan aman oleh semua } \\
\text { orang }\end{array}$ & 4,5714 \\
\hline 5 & $\begin{array}{l}\text { Alat pembuka tutup galon yang dapat mengurangi resiko cidera saat } \\
\text { membuka tutup galon }\end{array}$ & 4,4286 \\
\hline 6 & Alat pembuka tutup galon memiliki pegangan yang tidak licin & 4,4286 \\
\hline 7 & Alat pembuka tutup galon memiliki fitur tambahan & 3,8571 \\
\hline 8 & $\begin{array}{l}\text { Alat pembuka tutup galon terbuat dari material yang aman, ringan, dan tahan } \\
\text { lama }\end{array}$ & 4,2857 \\
\hline 9 & Alat pembuka tutup galon memiliki bentuk yang sesuai dengan tutup galon & 4 \\
\hline
\end{tabular}




\begin{tabular}{ccc}
\hline No & Voice of Customer (VOC) & $\begin{array}{c}\text { Nilai Kepentingan } \\
\text { Pelanggan }\end{array}$ \\
\hline $\mathbf{1 0}$ & Alat pembuka tutup galon memiliki bentuk dengan diameter yang adjustable & 4,1429 \\
$\mathbf{1 1}$ & Alat pembuka tutup galon memiliki warna yang cerah & 3,1429 \\
$\mathbf{1 2}$ & Alat pembuka tutup galon memiliki harga yang terjangkau & 4,1429 \\
\hline
\end{tabular}

\section{Technical Response}

Technical response berisi karakteristik atau spesifikasi produk untuk memenuhi dan menjawab VOC. Tabel 5 menunjukkan technical response. Berdasarkan Tabel 5 dapat dilihat bahwa terdapat 10 technical response yaitu jumlah gerakan dalam penggunaan alat, tenaga yang digunakan, berat alat, diameter pegangan, panjang pegangan, jumlah fitur tambahan pada alat, diameter alat pembuka tutup galon, penggunaan material pada alat (plastik atau stainless steel), pemilihan warna (merah, kuning, hijau), dan manufacturing cost.

Tabel 5. Technical Response

\begin{tabular}{cl}
\hline No & \multicolumn{1}{c}{ Technical Response } \\
\hline $\mathbf{1}$ & Jumlah gerakan dalam penggunaan alat \\
$\mathbf{2}$ & Tenaga yang digunakan \\
$\mathbf{3}$ & Berat alat \\
$\mathbf{4}$ & Diameter pegangan \\
$\mathbf{5}$ & Panjang pegangan \\
$\mathbf{6}$ & Jumlah fitur tambahan pada alat \\
$\mathbf{7}$ & Diameter alat pembuka tutup galon \\
$\mathbf{8}$ & Penggunaan material pada alat (plastik atau \\
& stainless steel) \\
$\mathbf{9}$ & Pemilihan warna (merah, kuning, hijau) \\
$\mathbf{1 0}$ & Manufacturing cost \\
\hline
\end{tabular}

\section{Relationship Matrix}

Relationship matrix menunjukkan keterkaitan hubungan antara VOC dengan technical response. Tabel 6 menunjukkan simbol dan bobot yang digunakan dalam penilaian. Berdasarkan Tabel 6 dapat dilihat bahwa terdapat 5 macam simbol yang digunakan dalam penilaian dengan bobot dari 0 hingga 8.

Tabel 6. Simbol dan Bobot Penilaian

\begin{tabular}{c|c|c}
\multicolumn{3}{c}{ Relationship Matrix } \\
\hline No & Simbol & Bobot \\
\hline 1 & X & 0 \\
\hline
\end{tabular}

\begin{tabular}{l|l|l}
2 & $\triangle$ & 2 \\
\hline 3 & $\bigwedge$ & 4 \\
\hline 4 & $\bigcirc$ & 6 \\
\hline 5 & $\bigcirc$ & 8 \\
\hline
\end{tabular}

Tabel 7 menunjukkan relationship matrix antara VOC dengan technical response. Berdasarkan Tabel 7 dapat dilihat bahwa terdapat 11 hubungan dengan skor 8,1 hubungan dengan skor 6,3 hubungan dengan skor 4, dan 2 hubungan yang saling bertentangan dengan skor 0 .

4. Technical Correlation

Technical correlation adalah keterkaitan hubungan antara setiap technical response. Simbol dan bobot yang digunakan sama dengan penilaian pada relationship matrix yang ditunjukkan pada Tabel 6. Gambar 3 menunjukkan technical correlation. Berdasarkan Gambar 3 dapat dilihat bahwa terdapat 4 hubungan dengan skor 8,1 hubungan dengan skor 6,1 hubungan dengan skor 4, 1 hubungan dengan skor 2, dan 2 hubungan yang saling bertentangan dengan skor 0 .

5. Nilai Kepentingan Absolut dan Relatif Perhitungan nilai kepentingan absolut dan relatif digunakan untuk mengetahui urutan prioritas perbaikan yang dapat dilakukan saat pengembangan produk. Tabel 7 menunjukkan hasil perhitungan nilai kepentingan absolut dan relatif. Berdasarkan Tabel 7 dapat dilihat bahwa nilai kepentingan absolut dan relatif tertinggi terletak pada technical response nomor 8 yaitu penggunaan material pada (plastik atau stainless steel) sedangkan nilai kepentingan absolut dan relatif terendah terletak pada technical response nomor 2 dan 10 yaitu tenaga yang digunakan dan manufacturing cost. 
Tabel 7. Relationship Matrix

\begin{tabular}{cll}
\hline No & \multicolumn{1}{c}{ Voice of Customer (VOC) } & \multicolumn{1}{c}{ Technical Response } \\
\hline $\mathbf{1}$ & $\begin{array}{l}\text { Alat pembuka tutup galon yang dapat digunakan dengan } \\
\text { mudah }\end{array}$ & Berat alat \\
$\mathbf{2}$ & $\begin{array}{l}\text { Alat pembuka tutup galon yang dapat membuka segel } \\
\text { galon dengan mudah }\end{array}$ & $\begin{array}{l}\text { Jumlah gerakan dalam penggunaan } \\
\text { alat }\end{array}$ \\
$\mathbf{3}$ & $\begin{array}{l}\text { Alat pembuka tutup galon yang dapat mengangkat tutup } \\
\text { galon dengan mudah setelah segelnya dibuka }\end{array}$ & Tenaga yang digunakan \\
$\mathbf{4}$ & $\begin{array}{l}\text { Alat pembuka tutup galon yang dapat digunakan dengan } \\
\text { aman oleh semua orang }\end{array}$ & Diameter Pegangan \\
$\mathbf{5}$ & $\begin{array}{l}\text { Alat pembuka tutup galon yang dapat mengurangi resiko } \\
\text { cidera saat membuka tutup galon }\end{array}$ & Berat alat \\
$\mathbf{6}$ & $\begin{array}{l}\text { Alat pembuka tutup galon memiliki pegangan yang tidak } \\
\text { licin }\end{array}$ & $\begin{array}{l}\text { Diameter Pegangan } \\
\text { Panjang pegangan }\end{array}$ \\
$\mathbf{7}$ & Alat pembuka tutup galon memiliki fitur tambahan & Jumlah fitur tambahan pada alat \\
$\mathbf{8}$ & $\begin{array}{l}\text { Alat pembuka tutup galon terbuat dari material yang } \\
\text { aman, ringan, dan tahan lama }\end{array}$ & $\begin{array}{l}\text { Manufacturing cost } \\
\text { Penggunaan material pada alat } \\
\text { (plastik atau stainless steel) }\end{array}$ \\
$\mathbf{9}$ dengan tutup galon & Diameter alat pembuka tutup galon \\
$\mathbf{1 0}$ & $\begin{array}{l}\text { Alat pembuka tutup galon memiliki bentuk dengan } \\
\text { diameter yang adjustable } \\
\text { Alat pembuka tutup galon memiliki warna yang cerah }\end{array}$ & Diameter alat pembuka tutup galon \\
$\mathbf{1 1}$ & Pemilihan warna (merah, kuning, \\
hijau) & Manufacturing cost \\
$\mathbf{1 2}$ & $\begin{array}{l}\text { Alat pembuka tutup galon memiliki harga yang } \\
\text { terjangkau }\end{array}$ & $\begin{array}{l}\text { Jumlah fitur tambahan pada alat } \\
\text { Penggunaan material pada alat } \\
\text { (plastik atau stainless steel) } \\
\text { Manufacturing cost }\end{array}$ \\
& &
\end{tabular}

\section{House of Quality (HOQ)}

Setelah setiap bagian HOQ telah dibuat maka dilanjutkan dengan membuat matriks HOQ secara keseluruhan. Gambar 4 menunjukkan matriks HOQ. Berdasarkan Gambar 4 dapat dilihat urutan prioritas perbaikan ke-1 hingga ke-10 secara berturut-turut yaitu (1) penggunaan material pada alat (plastik atau stainless steel), (2) berat alat, (3) diameter pegangan, (4) diameter alat pembuka tutup galon, (5) jumlah fitur tambahan pada alat, (6) jumlah gerakan dalam penggunaan alat, (7) panjang pegangan, (8) tenaga yang digunakan, (9) pemilihan warna (merah, kuning, hijau), dan (10) manufacturing cost. 
Versi Online: http://journal.ubm.ac.id/index.php/digismantech DOI : dx.doi.org/10.30813/digismantech.v1i1.2337.g2080 Hasil Penelitian
Jurnal Digismantech

Vol 1 (No. 1 ) : 46 - 59. Th. 2021 p-ISSN: 2798-1819 e-ISSN: 2798-0189

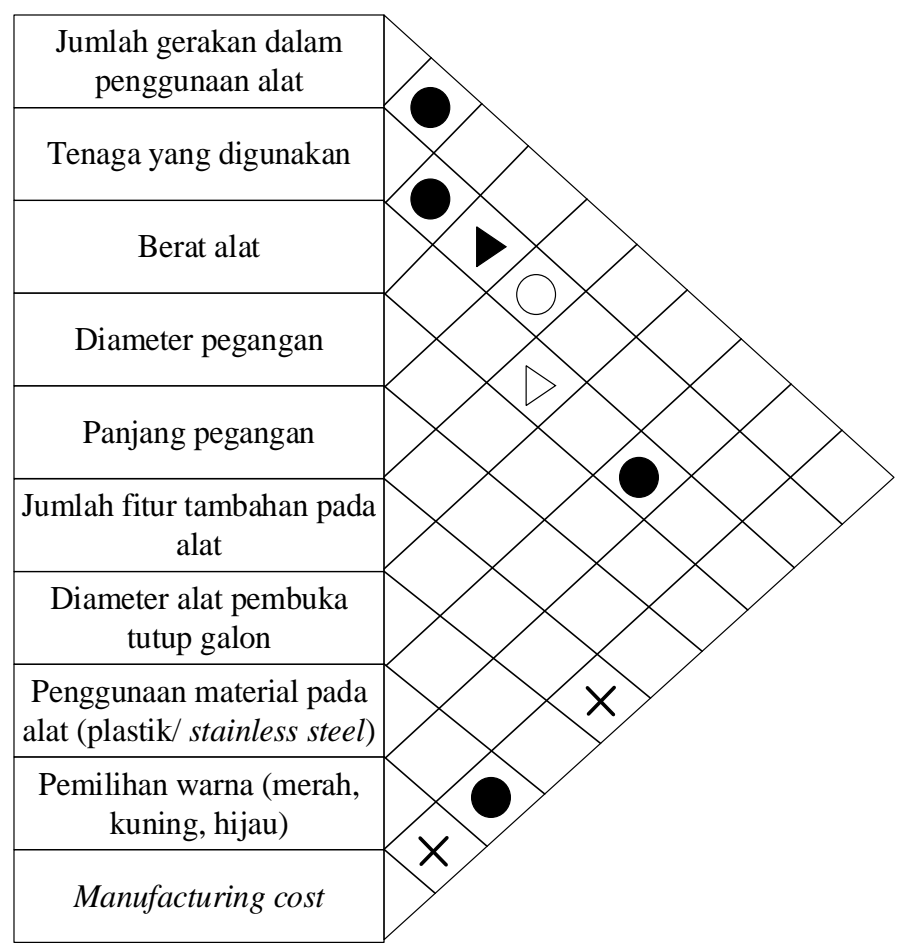

Gambar 3. Technical Correlation

Tabel 7. Nilai Kepentingan Absolut dan Relatif

\begin{tabular}{clcc}
\hline No & \multicolumn{1}{c}{ Technical Response } & $\begin{array}{r}\text { Nilai Kepentingan } \\
\text { Absolut }\end{array}$ & $\begin{array}{c}\text { Nilai Kepentingan Relatif } \\
(\boldsymbol{\%})\end{array}$ \\
\hline $\mathbf{1}$ & Jumlah gerakan dalam penggunaan alat & 35,4288 & 8,0677 \\
$\mathbf{2}$ & Tenaga yang digunakan & 33,1432 & 7,5472 \\
$\mathbf{3}$ & Berat alat & 59,7148 & 13,5979 \\
$\mathbf{4}$ & Diameter pegangan & 53,7144 & 12,2316 \\
$\mathbf{5}$ & Panjang pegangan & 35,4288 & 8,0677 \\
$\mathbf{6}$ & Jumlah fitur tambahan pada alat & 47,4284 & 10,8002 \\
$\mathbf{7}$ & Diameter alat pembuka tutup galon & 48,5716 & 11,0605 \\
$\mathbf{8}$ & Penggunaan material pada alat (plastik atau & 67,4288 & 15,3546 \\
& stainless steel) & & \\
$\mathbf{9}$ & Pemilihan warna (merah, kuning, hijau) & 25,1432 & 5,7255 \\
$\mathbf{1 0}$ & Manufacturing cost & 33,1432 & 7,5472 \\
\hline
\end{tabular}




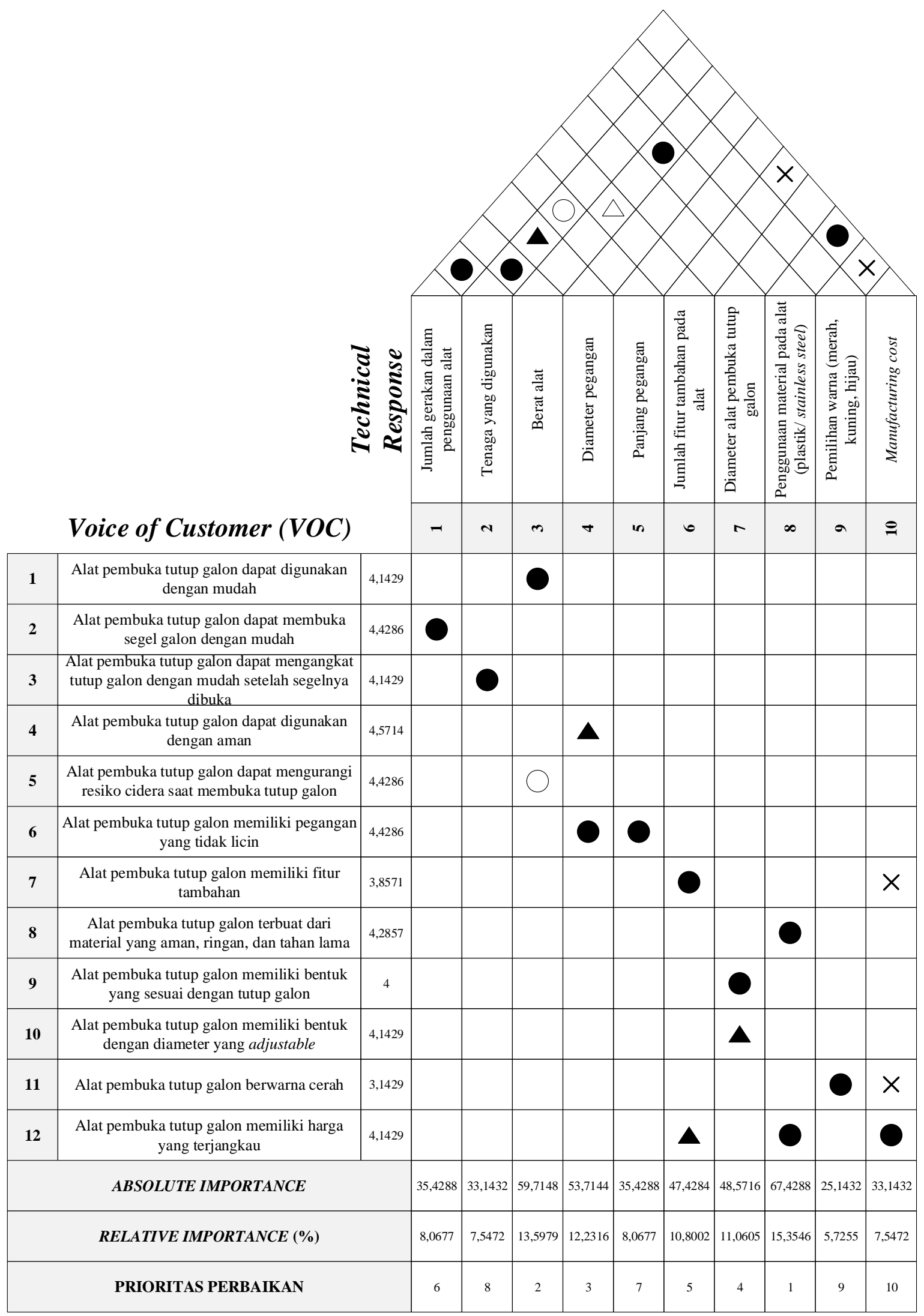

Gambar 4. Matriks House of Quality (HOQ) 


\section{SIMPULAN}

Berdasarkan hasil analisis yang telah diperoleh, terdapat 12 VOC yang diperoleh dari hasil interpretasi kebutuhan pelanggan. Terdapat 10 technical response yang digunakan untuk menjawab setiap VOC. Urutan prioritas perbaikan pengembangan produk yang dapat dilakukan berdasarkan matriks HOQ secara berturut-turut yaitu (1) penggunaan material pada alat (plastik atau stainless steel), (2) berat alat, (3) diameter pegangan, (4) diameter alat pembuka tutup galon, (5) jumlah fitur tambahan pada alat, (6) jumlah gerakan dalam penggunaan alat, (7) panjang pegangan, (8) tenaga yang digunakan, (9) pemilihan warna (merah, kuning, hijau), dan (10) biaya produksi.

Penelitian yang akan datang dapat melanjutkan metode QFD sampai dengan pembuatan desain dan produksi produk. Selain itu, penelitian selanjutnya dapat melakukan benchmarking dengan produk pesaing. Perhitungan biaya produksi dan biaya transportasi dapat diperhitungkan dari produk yang telah dikembangkan sehingga dapat mengetahui harga jual yang sesuai (Filscha Nurprihatin \& Regent Montororing, 2021). Penelitian selanjutnya dapat melakukan klasterisasi terhadap konsumen untuk memberikan produk sesuai dengan segmentasi pasar (Filscha Nurprihatin, 2016b; Rembulan, Wijaya, Palullungan, et al., 2020). Pada tahap produksi massal, produk yang sudah dirancang harus dalam jumlah output yang optimal (F. Nurprihatin \& Lestari, 2020; Regina et al., 2020). Kondisi optimal dapat juga berarti biaya yang rendah (Archana et al., 2021). Penelitian selanjutnya juga dapat mempertimbangkan optimalisasi biaya operasional (Filscha Nurprihatin, Regina, et al., 2021; Regent Montororing \& Nurprihatin, 2021; Rembulan, Luin, Julianto, et al., 2020) sekaligus menjamin kelancaran produksi (Karo-Karo et al., 2017) atau mengurangi pemborosan (Filscha Nurprihatin, Darvin, et al., 2017; Filscha Nurprihatin, Yulita, et al., 2017). Pemborosan yang dapat dikurangi adalah makespan dengan melakukan rekayasa pada penjadwalan produksi (Filscha Nurprihatin, 2016a; Filscha Nurprihatin et al., 2020) dan penjadwalan pengiriman yang baik (Filscha Nurprihatin, Elvina, et al., 2021). Pemborosan lainnya juga dapat dibahas seperti waktu tempuh (Filscha Nurprihatin et al., 2019).

\section{DAFTAR PUSTAKA}

Aguwa, C., Olya, M. H., \& Monplaisir, L. (2017). Modeling of Fuzzy Based Voice of Customer for Business Decision Analytics. Knowledge Based Systems, 125, 136-145. https://doi.org/10.1016/j.knosys.2017.03.0 19

Alsaadi, M. R., Ahmad, S. Z., \& Hussain, M. (2018). A Quality Function Deployment Strategy for Improving Mobile Government Service Quality in The Gulf Cooperation Council Countries. Benchmarking, 25(8), 3276-3295. https://doi.org/10.1108/BIJ-12-2017-0333

Archana, G., Mani, V., Nguyen, D. D., Ravindran, B., Rembulan, G. D., La, D. D., Chang, S. W., \& Nguyen, X. H. (2021). In-Vitro disintegration and dissolution of facile synthesised vegetable capsule films from Abelmoscus esculentus and Gracilaria corticata polysaccharides. Progress in Organic Coatings, 155. https://doi.org/10.1016/j.porgcoat.2020.10 6012

Badan Pusat Statistik. (2019). Distribusi Persentase Rumah Tangga Menurut Provinsi dan Sumber Air Minum 2019. https://www.bps.go.id/indikator/indikator/ view_data_pub/0000/api_pub/100/da_04/ 1

Bolar, A., Tesfamariam, S., \& Sadiq, R. (2017). Framework for Prioritizing Infrastructure User Expectations Using Quality Function Deployment (QFD). International Journal of Sustainable Built Environment, 6(1), 16-29.

https://doi.org/10.1016/j.jisbe.2017.02.00 2

Cahya, H. N. (2018). Optimalisasi Kualitas Produk Layanan Purna Jual Chevrolet Sumber Andalan Jogja dengan Pendekatan Qfd. Jurnal Penelitan Ekonomi Dan Bisnis, 3(2), 91-100. https://doi.org/10.33633/jpeb.v3i2.2301

Christian, M., \& Rembulan, G. D. (2019). Pendampingan Membuat Strategi 
Pengukuran Evaluasi Kegiatan pada Organisasi Ruang Publik Terpadu Ramah Anak (RPTRA). Jurnal Pengabdian Dan Kewirausahaan, 3(2), 134-143.

Dehe, B., \& Bamford, D. (2017). Quality Function Deployment and Operational Design Decisions A Healthcare Infrastructure Development Case Study. Production Planning and Control, 28(14), 1177-1192. https://doi.org/10.1080/09537287.2017.13 50767

Ekawati, Y., \& Bazarado, M. (2016). Designing Food Products Based on Carrots Using the Product Design Phase of Quality Function Deployment. ARPN Journal of Engineering and Applied Sciences, 11(5), 3109-3116.

Erdil, N. O., \& Arani, O. M. (2018). Quality Function Deployment: More than A Design Tool. International Journal of Quality and Service Sciences, 11(2), 142166. https://doi.org/10.1108/IJQSS-022018-0008

Ho, W. C., Lee, A. W., Lee, S. J., \& Lin, G. T. R. (2018). The Application of Quality Function Deployment to Smart WatchesThe House of Quality for Improved Product Design. Journal of Scientific and Industrial FResearch, 77(3), 149-152.

Karo-Karo, G., Lois, C., \& Nurprihatin, F. (2017). Usulan Perencanaan dan Pengendalian Baku Boks Panel dengan Menggunakan Metode Material Requirements Planning (MRP). Prosiding Seminar Nasional Akuntansi Dan Bisnis, 923-933.

Kasan, A., \& Yohanes, A. (2017). Improvement Produk Hammock Sleeping Bag dengan Metode Quality Function Deployment (QFD). Dinamika Teknik, 10(1), 40-49.

Kementerian Perindustrian. (2019). Investasi Mengalir di Bisnis Air Minum. https://kemenperin.go.id/artikel/20136/Inv estasi-Mengalir-di-Bisnis-Air-Minum

Klochkov, Y., Klochkova, E., Volgina, A., \& Dementiev, S. (2016). Human Factor in Quality Function Deployment. 2016 Second International Symposium on Stochastic Models in Reliability
Engineering, Life Science and Operations Management, $\quad$ 466-468. https://doi.org/10.1109/SMRLO.2016.81

Lusiani, M., Yuirafat, A., \& Tannady, H. (2017). Analisis Kepuasan Pengguna BPJS dan Non BPJS terhadap Layanan Rumah Sakit dengan Model Quality Funcion Deployment. Prosiding Seminar Nasional Akuntansi Dan Bisnis, 10111017.

Muttalib, S. A., Hidayat, A. F., Abdillah, S. H., Widhiantari, I. A., Rozidi, R., \& Burhan, S. (2020). Pengembangan Desain Sprayer Buah Menggunakan Quality Function Deployment. Jurnal Teknik Pertanian Lampung, 9(2), 149-156. https://doi.org/10.23960/jtep-l.v9i2.149156

Nurprihatin, F., \& Lestari, A. (2020). Waste collection vehicle routing problem model with multiple trips, time windows, split delivery, heterogeneous fleet and intermediate facility. Engineering Journal, 24(5). https://doi.org/10.4186/ej.2020.24.5.55

Nurprihatin, Filscha. (2016a). Penentuan ukuran batch pada batch processor untuk meminimasi makespan. Jurnal Metris, 17, 43-50.

Nurprihatin, Filscha. (2016b). Penentuan Pusat Distribusi Ritel dengan Analisis K-Means Clustering (Studi Kasus PT. XYZ di Kalimantan). Seminar Nasional Teknologi Dan Sains II, TI-10-TI-19.

Nurprihatin, Filscha, Andry, J. F., \& Tannady, H. (2021). Setting the natural gas selling price through pipeline network optimization and project feasibility study. Journal of Physics: Conference Series, 1811(1). https://doi.org/10.1088/17426596/1811/1/012008

Nurprihatin, Filscha, Darvin, C., Karo-Karo, G., \& Caesaron, D. (2017). Implementasi Lean Manufacturing pada Proses Produksi untuk Mengurangi Pemborosan Persediaan. Prosiding Seminar Nasional Teknologi Dan Informatika, 741-749.

Nurprihatin, Filscha, Elnathan, R., Rumawan, R. E., \& Regina, T. (2019). A distribution strategy using a two-step optimization to maximize blood services considering 
stochastic travel times. IOP Conference Series: Materials Science and Engineering, $\quad 650(1)$. https://doi.org/10.1088/1757899X/650/1/012043

Nurprihatin, Filscha, Elvina, Rembulan, G. D., Christianto, K., \& Hartono, H. (2021). Decision support system for truck scheduling in logistic network through cross-docking strategy. Journal of Physics: Conference Series, 1811(1). https://doi.org/10.1088/17426596/1811/1/012009

Nurprihatin, Filscha, Jayadi, E. L., \& Tannady, H. (2020). Comparing heuristic methods' performance for pure flow shop scheduling under certain and uncertain demand. Management and Production Engineering Review, 11(2), 50-61. https://doi.org/10.24425/mper.2020.13372 8

Nurprihatin, Filscha, \& Regent Montororing, Y. D. (2021). Improving vehicle routing decision for subsidized rice distribution using linear programming considering stochastic travel times. Journal of Physics: Conference Series, 1811(1). https://doi.org/10.1088/17426596/1811/1/012007

Nurprihatin, Filscha, Regina, T., \& Rembulan, G. D. (2021). Optimizing rice distribution routes in Indonesia using a two-step linear programming considering logistics costs. Journal of Physics: Conference Series, 1811(1). https://doi.org/10.1088/17426596/1811/1/012010

Nurprihatin, Filscha, Yulita, N. E., \& Caesaron, D. (2017). Usulan Pengurangan Pemborosan pada Proses Penjahitan Menggunakan Metode Lean Six Sigma. Prosiding Seminar Nasional Akuntansi Dan Bisnis, 809-818.

Padagannavar, P. (2016). Automotive Product Design and Development of Car Dashboard Using Quality Function Deployment. International Journal of Industrial Engineering Research and Development, 7(1), 10-23. https://doi.org/10.4172/21677670.1000136

Piri, N. I., Sutrisno, A., \& Mende, J. (2017).
Penerapan Metode Quality Function Deployment (QFD) untuk Menangani Non Value Added Activiy pada Proses Perawatan Mesin. Jurnal Online Poros Teknik Mesin, 6(1), 10-19.

Priyono, A. (2016). Improving the Quality of Public Transportation Using Quality Function Deployment and Kano's Model. International Conference on Industrial Enginering and Operations Management, 2699-2708.

Ramadhan, B. (2020). Air Minum Kemasan Galon Guna Ulang Masih Jadi Pilihan. https://republika.co.id/berita/qbm8s1330/a ir-minum-kemasan-galon-guna-ulangmasih-jadi-pilihan

Regent Montororing, Y. D., \& Nurprihatin, F. (2021). Model of quality control station allocation with consider work in process, and defect probability of final product. Journal of Physics: Conference Series, 1811(1). https://doi.org/10.1088/17426596/1811/1/012013

Regina, T., Luin, J. A., \& Rembulan, G. D. (2020). Mengurangi keterlambatan waktu produksi menggunakan line balancing pada sektor konstruksi jalan tol. Prosiding Seminar Nasional Riset Dan Teknologi, 258-263.

Rembulan, G. D. (2017). Pengaruh Pendidikan Kewirausahaan terhadap Minat Berwirausaha. Jurnal Pengabdian Dan Kewirausahaan, 1(1), 65-73.

Rembulan, G. D. (2018). Faktor-faktor yang Memengaruhi Getok Tular pada Usaha Restoran Waralaba di Jakarta. Jurnal Pengabdian Dan Kewirausahaan, 2(1), 17-28.

Rembulan, G. D. (2019). Pengembangan Industri Kecil dan Menengah Tiwul Instan sebagai Alternatif Pendukung Ketahanan Pangan dalam Perspektif Konsumen. Industria: Jurnal Teknologi Dan Manajemen Agroindustri, 8(2), 87-94. https://doi.org/10.21776/ub.industria.2019 .008 .02 .2

Rembulan, G. D. (2020). Analisis Faktor Keselamatan Lingkungan Belajar dan Bermain untuk Anak di RPTRA Sunter Jaya Berseri. Jurnal Pengabdian Dan Kewirausahaan, 4(1), 58-65. 
Rembulan, G. D., Luin, J. A., Julianto, V., \& Septorino, G. (2020). Optimalisasi Panjang Jaringan Pipa Air Bersih di DKI Jakarta Menggunakan Minimum Spanning Tree. Jurnal Intech, 6(1), 7587.

https://doi.org/10.30656/intech.v6i1.2164

Rembulan, G. D., Sunarti, T. C., \& Meryandini, A. (2015). Penambahan Bakteri Asam Laktat Terenkapsulasi untuk Menekan Pertumbuhan Bakteri Patogen pada Proses Produksi Tapioka. Jurnal Teknologi Dan Industri Pangan, 26(1), 34-43. https://doi.org/10.6066/jtip.2015.26.1.34

Rembulan, G. D., Wijaya, T., Palullungan, D., Alfina, K. N., \& Qurthuby, M. (2020). Kebijakan Pemerintah Mengenai Coronavirus Disease (COVID-19) di Setiap Provinsi di Indonesia Berdasarkan Analisis Klaster. Journal of Industrial Engineering and Management Systems, 13(2), 74-86. https://doi.org/10.30813/jiems.v13i2.2280

Rembulan, G. D., Wijaya, T., Ruslie, A., Jordy, \& Sunadynatha, R. A. S. (2020). Mereduksi Voice of Customer pada Pengembangan Produk Alat Pembuka Tutup Galon Menggunakan Analisis Faktor. Journal of Industrial Engineering and Management Systems, 13(2), 87-99. https://doi.org/10.30813/jiems.v13i2.2281

Rini, A. S. (2019). Investasi Industri Air Minum Kemasan Terus Tumbuh. https://ekonomi.bisnis.com/read/2019071 1/257/1123195/investasi-industri-airminum-kemasan-terus-tumbuh

Ritonga, M. M., Halim, S., \& Sulaiman, F. (2018). Analisis Peningkatan Kualitas Pengajaran Bahasa Inggris dengan Metode Teoriya Resheniya Izobreta Telskikh Zadatch (Triz) \& Quality Function Deployment (QFD) (Studi Kasus: Politeknik LP3I Medan dan Universitas Muhammadiyah Sumatera Utara). Jurnal Bisnis Administrasi, 7(2), 22-28.
Sachamanorom, W., \& Senoo, D. (2016). Voice of the Customer Through Customer Cocreation: The Case of Fuji Xerox Japan. Pacific Asia Conference on Information Systems, 1-14.

Singh, A. K., \& Rawani, A. M. (2019). Application of Quality Function Deployment for The Prioritization of National Board of Accreditation Quality Parameters. Quality Assurance in Education, 27(1), 127-139. https://doi.org/10.1108/QAE-11-20170078

Sofyan, D. K., \& Amri. (2018). Aplikasi Matriks Quality Function Deployment (QFD) pada Perancangan Ulang Meja Belajar Mini. Jurnal Optimalisasi, 3(5), 103-116. https://doi.org/10.35308/jopt.v3i5.275

Sukania, I. W., Salomon, L. L., \& Dharmawan, O. (2017). Usulan Perbaikan Kualitas Produk Plastik dengan Metode Quality Function Deployment di PT.X. Jurnal Ilmiah Teknik Industri, 5(2), 63-69.

Sulistiyoningrum, C. E., Jufrizal, \& Mulia, A. (2017). Go-Scufy: Redesain Produk Sepatu Wanita Berbahan Karung Goni Menggunakan Metode Quality Function Deployment. Jurnal Ilmiah Teknik Industri, 16(1), 40-47. https://doi.org/10.23917/jiti.v16i1.3848

Tannady, H. (2015). Pengendalian Kualitas. Graha Ilmu.

Yushila, A. B., Effendi, M., \& Effendi, U. (2017). Analisis Kepuasan Konsumen dengan Metode Fuzzy Servqual dan Quality Function Deployment (Studi Kasus Cafe Right Time Malang). Jurnal Teknologi Pertanian, 18(2), 107-118.

Yustian, O. R. (2015). Analisis Pengembangan Produk Berbasis Quality Function Deployment (QFD) (Studi Kasus pada Produk Susu PT. MSA). Jurnal Ekonomi Dan Bisnis, 18(3), 23-42. https://doi.org/10.24914/jeb.v18i3.279 